\title{
FUNÇÃO DO INEFÁVEL E DO INSÓLITO NA NARRATIVA: "O OVO E A GALINHA" E ÁGUA VIVA DE CLARICE LISPECTOR
}

LOSSO, Eduardo Guerreiro Brito

\section{Dosagem da subversão}

Lucia Helena introduz uma proposta de historicização da literatura da primeira metade do século $X X$ baseada numa diferença de tratamento da narrativa. Há no alto modernismo brasileiro um privilégio do paradigma experimental, contra o entendimento fácil do leitor e a cartilha do realismo, da década de 20. Na década de 30 aparece o romance social, aprimorando o realismo anterior com o retrato mais consciente dos elementos ambientais, econômicos e históricos do Brasil, repudiando o experimentalismo. O protesto contra as injustiças sociais se torna "esteticamente pouco inventivo" (LAFETÁ, 2000: 34-35). Na década de 40, quando aparecem Guimarães Rosa e Clarice Lispector, há um experimentalismo que não recusa a forma narrativa, mas usaa para a subverter com uma correlação mais ampla do regional, nacional e existencial (HELENA, 1992: 1164).

A partir daí podemos refletir que o experimentalismo não é mais visto como um valor em si, porém faz parte de uma estratégia com vistas a potencializar o questionamento reflexivo e a experiência estética do texto literário. Sabe-se que o modernismo brasileiro, nas palavras de Luiz Lafetá, possui um projeto ideológico, busca de uma expressão nacional, e um projeto estético, ruptura da linguagem tradicional (LAFETÁ, 2000, p. 20-21). Somente a partir do final dos anos 20 as melhores obras começam a sair, e os anos 30 foram os mais esteticamente felizes para essa geração. Não interessa que a experimentação resulte simplesmente no insólito, mas que o insólito seja existencialmente fundamentado. Nesse caso, importa menos o fato de as supostas estruturas tradicionais narrativas serem subvertidas ou parcialmente mantidas do que a função de dosagem da subversão para a exploração do potencial investigativo e epifânico da existência. O princípio de encadeamento lógico inteligível de uma narração em geral não é nem completamente 
subvertido nem obedecido, porém manipulado de acordo com o desejo de embriaguez e gnose estética (BROEK, 1998: 231) por meio da linguagem que ora ordena parcialmente os acontecimentos e os argumentos, ora desarranja o todo por vezes até o extremo da radicalidade.

De qualquer forma, são obras que não chegaram a um estágio histórico posterior pós-moderno (o que para muitos é uma qualidade) de retomar modelos de inteligibilidade para subvertê-los sem violência, ou, transgredindo, fazê-lo de um modo atraente, daí o videoclip pós-moderno, por exemplo, assimilar o surrealismo com grande facilidade (ver o capítulo "Video. Surrealism Without the Unconscious", em JAMESON, 1991: 67-96; CONNOR, 1992: 129148). Entre os produtos totalmente mergulhados na lógica da indústria cultural e a literatura pós-moderna há um hiato visível de que no último ainda encontramos resistência, mesmo quando suave e estratégica, à estandartização, mesmo sem abrir mão do apelo ao consumo. Entre o valor estético e o valor de entretenimento várias apostas são lançadas. Podemos exemplificar aqui livros como o de Rubem Fonseca.

Os casos de Rosa e Clarice estão bem distantes deste novo paradigma, pois seu experimentalismo, se não é somente lingüístico e material, é mais amplo e abarca a relação do texto com a experiência. Por isso pode até se tornar, num certo sentido, mais intragável para o leitor semiformado pela indústria cultural, não só por motivos de inteligibilidade, mas razões, por assim dizer, psicológicas. Como afirma José Guilherme Merquior, "Caberia a mestres neomodernos como Guimarães Rosa e Clarice Lispector comprometer as letras brasileiras com a 'participação nas trevas'” (MERQUIOR, 1980: 38), referindose à expressão do Adorno de Teoria estética, Methexis am Finsteren (MERQUIOR, 1980: 37).

Por outro lado, leitores bem preparados podem também não assimilálos. Há muitos que vêem na densidade existencial de Clarice um fator mais piegas, subfilosófico, forçado e pretensioso do que justificado. No conto "O ovo e a galinha", por exemplo, frases como "Será que sei do ovo? É quase certo que sei. Assim: existo, logo sei" (LISPECTOR, 1991: 57) podem provocar repulsa pela sua inserção fragmentária e aparentemente arbitrária. Foi o que aconteceu, num primeiro momento da leitura da obra até $A$ paixão segundo $G$. 
H., com Luiz Costa Lima: “... que acolhia uma matéria já gasta, já vista, envelhecida pelo sentimentalismo romântico, mal disfarçado pelas vestes mais recentes de um jargão existencializado" (LIMA, 1966: 101). Já Benedito Nunes reconhece nesse mesmo trecho uma "paródia filosófica" (NUNES, 1989: 92; ver também PONTIERI, 1999: 214). A entrada de reflexão especulativa na literatura, que não está ausente dos princípios do romance moderno - tendo um ponto de cristalização em Dostoievski , por exemplo no capítulo "o grande inquisidor" de Os irmãos Karamazov (lembro a comparação de Adonias Filho do monólogo de Dostoievski e Clarice, FILHO, 1965: 81-83); em Proust e Musil passa a ter caráter de ensaio, interferindo no tempo narrativo (RICOEUR, 1984: 143-145) - chega a um ponto de negação do enredo, da ação narrativa, o que levou Assis Brasil a constatar que na obra da autora (e acrescento, principalmente no conto e no livro que analisaremos) "morre a narrativa, como narrativa 'relatada"' (BRASIL, 1969: 50) ou o que Benedito Nunes chama de "improviso": " a escritura se desenrola ao léu de múltiplos temas e motivos recorrentes" (NUNES, 1989: 169). Rosa não sofre esse tipo de repulsa precisamente por que, na maioria das vezes, não deixa de contar "estórias", por mais herméticas que por vezes sejam, como no conto "Nenhum, nenhuma" de Primeiras estórias.

Contudo, é necessário, nesse caso, direcionar a análise para outros procedimentos tão narrativos quanto à ação. Se há narratividade em quase toda manifestação da linguagem humana, se encontramos estruturas narrativas em textos filosóficos (é o pressuposto da narrative turn em ciências humanas), por que não haveria na literatura experimental? A teoria da narrativa atual, ao abandonar os paradigmas estruturalistas dos anos 60 e 70, está tentando dar conta justamente do exame de questões que não aparecem apenas na análise de procedimentos textuais, mas também na relação entre texto e leitura, texto e contexto, etc. Logo, para reconhecer o lugar onde a teoria narrativa pode melhor se renovar, é necessário procurar entender o que se passa justamente nos textos em que a análise da narrativa tradicional teria pouco a dizer, sem deixar de aproveitar o próprio esforço do formalismo e do estruturalismo ao lidar com esse tipo de texto, que rendeu bons frutos em sua época, como foi o caso das análises de Gerard Genette, entre outros. 


\section{Texto e experiência do inefável}

Em Clarice e Rosa a atividade discursiva procura dar a maior ênfase naquilo que podemos chamar de instância inefável ligada ao insólito. A dificuldade e o experimentalismo estão a serviço de tentar expressar artisticamente algo da ordem do indizível de modo não convencional. É pressuposto que o desafio da alta literatura é dizer algo mais que a filosofia por meio de seus procedimentos narrativos. Isso faz parte do lugar da literatura como meio de expressão elevado de uma cultura. Contudo, para além desse fator muito geral, uma especificidade destes dois escritores (tendo como precursor bem conhecido e internacional a epilepsia epifânica de Dostoievski) está no fato de que toda a ânsia discursiva está ligada à expressão não só do indizível em geral, mas da experiência do inefável. Quando digo "expressão" significa tanto um anseio dos autores (implícitos ou mesmo empíricos, mas figurados em narradores extremamente conflituosos e especulativos) por dar voz literária a suas experiências imaginadas - pressuposto da epifania-visão do primeiro Joyce comparada a de Clarice por Olga de Sá (SÁ, 1993: 192) - como suscitar, através da escrita e da leitura, tal experiência através da epifanialinguagem, incorporada e revelada na palavra. Muitos críticos, em especial Benedito Nunes e Olga de Sá, reconheceram a implicação mútua entre experiência e escritura, o que vai nos ser muito útil, mas nosso propósito é avançar a problemática.

Essa dupla faceta da íntima ligação entre texto e experiência do excesso, em que não existe ou não interessa a pré-existência de um sobre o outro, já foi pensada em abordagens desconstrucionistas. Minha contribuição ocorrerá a partir desse ponto, levando em conta dimensões que a desconstrução não explorou embora intuiu. Se ela reconheceu a dimensão da experiência textual (MENKE, 1998: 181-182) liberando as estratégias complexas da escritura e suas disseminações de diferença diante da fuga inapreensível de traços e rastros, que constituem a inefabilidade da differance derridiana e do real lacaniano, vamos aprofundar uma análise das possibilidades práticas de experiência do efeito da obra na vida do leitor e da dimensão prática da escrita inerente à obra. A crítica clariceana nos mostra alguns insights pouco desenvolvidos desse fenômeno, mas recai na primazia 
da escritura sobre a prática, como é caso, especialmente, de Olga de Sá (mesmo levando em conta a teoria de Jauss da recepção da crítica), quando ressalta a "significação [...] dessa experiência prática da escritura" em Joyce (SÁ, 1993, p. 177).

Quando digo prática, não quero dizer no sentido político, porém no sentido das possibilidades concretas de experiência do inefável, em outras palavras, a experiência mística. Ainda que a desconstrução e a psicanálise tenham vários momentos de sugestões teóricas vagas do destino místico da experiência literária, não focaram como isso ocorre. Já que a literatura moderna produz incessantemente a crítica à religião, ideologia e metafísica, como tantas abordagens já insistiram, agora é preciso pensar como, depois da derrocada da metafísica, há nesta mesma literatura a ascensão de uma mística sem doutrina, sem sustentação religiosa oficial, enfim, uma mística moderna, uma mística da literatura moderna (WAGNER-EGELHAAF, 1989: 60). Olga de Sá está próxima dessa abordagem quando pondera que "a graça da epifania é uma espécie de graça profana; não é a graça dos santos" (SÀ, 1993: 201), mas a sistematização do problema foi feita de fato pela teoria da literatura francesa, com Michel Carrouges, e alemã, com Wolfgang Böhme, Wagner-Egelhaaf e Uwe Spörl (para um panorama, ver LOSSO, 2007: 281-287). A mística da literatura moderna afirma o inefável não por meio de uma positividade transcendente (entidades como Deus, idéias como o Bem, conceitos como a liberdade, crenças como vida após a morte, etc.), mas pela negatividade radical da ficcionalidade. O trabalho com a forma é, desse modo, feito não só com vistas a um objeto estético, mas a uma experiência e um saber impreciso (ou "saber imediato arraigado à percepção em estado bruto" NUNES, 1989: 123), anti-empírico, intransmissível, que chamo aqui de gnose, à qual tal objeto está a serviço (LAYTON, 2002: 145). A experiência e a gnose conduzem a uma transformação da vida ordinária, a uma espécie de vida extraordinária que a transfiguração do olhar diante do mundo poderia trazer. Se isso não é uma crença, é sem dúvida a grande aposta dessa mística estética. Para ver a bibliografia e uma discussão teórica sobre o assunto, remeto à minha tese (LOSSO, 2007, p. 174-309). Para tratar dessa aposta prática da escrita literária, faremos uma análise dos textos e em seguida concluiremos com o 
nosso posicionamento diante do que a crítica da autora pensou a esse respeito.

\title{
3. Renegar e proteger
}

Não posso pensar de outra forma trechos como esse:

\begin{abstract}
Sou indispensavelmente um dos que renegam. Faço parte da maçonaria dos que viram uma vez o ovo e o renegam como forma de protegê-lo. Somos agentes disfarçados e distribuídos pelas funções menos reveladoras, nós às vezes nos reconhecemos (LISPECTOR, 1991: 62).
\end{abstract}

Há no conto "O ovo e a galinha" um eu indeterminado que funciona como narrador. Sabemos vagamente ser uma personagem feminina, que trabalha com ovos, possivelmente uma cozinheira: "só entendo o ovo quebrado: quebro-o na frigideira" (LISPECTOR, 1991: 62). O grau especulativo da reflexão destoa bastante dessa possibilidade, mas a contradição faz parte da tensão narrativa, que não existe para ser coerente, mas para jogar informações e dados totalmente díspares (outra característica do "improviso" de Benedito Nunes). Num momento a narradora afirma que é empregada e supostamente não ganha muito, mas em outro declara faceiramente que "ultimamente comprei ações da Brahma e estou rica" (LISPECTOR, 1991: 65), logo, não haveria necessidade nenhuma de continuar a trabalhar. Não há dúvida que aqui o "improviso" quer ser dissonante, em termos de coerência, fenômeno que depois, no romance pós-moderno, será generalizado.

No entanto, esse improviso pouco foi pensado em termos de seu efeito no leitor. A leitura que vai tentando dar coerência a tais disparidades passa a criar ela mesma a tensão textual, que com o costume de sua recorrência forma uma idéia aproximada da situação e aceita as contradições como parte do mundo textual possível. Ligações coerentes e tensões incoerentes formam então um horizonte de leitura que diferenciará suas zonas de validade, sua verossimilhança interna. A partir daí, a busca de uma fruição possível do texto se dará no uso da liberdade interpretativa que as incoerências permitem e as coerências delimitam.

No trecho acima citado, "ver o ovo" pode significar ter a experiência extraordinária, graça só reservada a poucos eleitos. Mas a "maçonaria" dos eleitos, coerente com a lógica das ordens esotéricas, não pode revelar o 
mistério, deve se calar. Porém a narradora vai mais longe e diz que deve "renegar o ovo" como "forma de protegê-lo"; quase como dizer que não teve a experiência mística para melhor a fazer valer numa sociedade laica por meio da possibilidade de dizer o não-dito na literatura, ou, como se quiser, fazê-lo atravessar o literal. Há um "nós", um mistério coletivizado extremamente enigmático para o leitor, que alterna com o "eu" da protagonista narradora (PONTIERI, 1999: 213) e o "ele" do ovo. Eles são "agentes disfarçados", caracterização que aventa um clima de expectativa ficcional detetivesca que, porém, mantém-se sem desenvolvimento. Tais agentes ocupam "funções menos reveladoras", até porque não podem assumir sua verdadeira função, mas se reconhecem uns aos outros. Essa modéstia que esconde um poder secreto maior justifica ironicamente um trecho anterior.

E ter apenas a própria vida é, para quem já viu o ovo, um sacrifício. Como aqueles que, no convento, varrem o chão e lavam a roupa, servindo sem a glória de função maior, meu trabalho é o de viver os meus prazeres e as minhas dores. É necessário que eu tenha a modéstia de viver (LISPECTOR, 1991: 62).

Ver o ovo é então um conhecimento secreto, gnóstico, que não só não pode ser dito, como deve ser renegado. O sacrifício e a modéstia dos agentes que "austeramente vivem todos os prazeres" (LISPECTOR, 1991: 63) é simplesmente ter, paradoxalmente, uma vida comum, sem o sofrimento dos mais desfavorecidos, nem a ascese rigorosa dos monges. A vida comum dos agentes que renegam o incomum mas o experienciam não é nada especial aos olhos comuns, mas seu sacrifício de ser comum e renegar o incomum é tão incomum quanto a vida no convento.

Nesta mística secularizada, há uma clara comparação com a mística tradicional, há semelhança com a vida do convento e com a maçonaria, mas na semelhança mesma, na incontornabilidade de a expressar por meio de alegorias da mística e da ascese religiosa já se põe o ato de diferenciação. A prática ascética ficcional proposta é claramente a de parecer ser comum, ter prazeres e dores comuns, e secretamente ser tão ou mais extraordinário que a ascese incomum do monge e do maçom. Logo, a tarefa do escritor-místico moderno é uma ascese da ascese, ascese de renunciar à ascese reconhecida pela sociedade na sua distinção definida do modo de vida profano e do modo 
de vida sagrado, de modo a experimentar o sagrado no interior das atividades e mesmo das posições estatutárias mais profanas. Benedito Nunes faz uma importante análise da ascese do despojamento especialmente em $A$ paixão segundo G.H. que evidencia o quanto as estruturas de renúncia da mística tradicional são pregnantes no obra de Clarice (NUNES, 1989: 41-42, 63-66, 72, 145). Contudo, Nunes não suspeita de que haja uma grande diferença entre a ascese tradicional e a da obra de Clarice, que haja um deslocamento considerável no processo de secularização.

No plano da forma narrativa, isso fica ainda mais claro. A suposta narradora "cozinheira" é no fundo uma agente secreta que não vai contar uma história com estrutura comum, não vai se revelar como uma personagem comum, vai dizer que comprou as ações da Brahma por puro capricho literário para confundir sua identidade, vai expor especulações exageradas, vai ser levada a flertar com o lírico, mas não vai se assumir nem como poema em prosa, nem enredo, nem como discurso filosófico.

Tal capricho não só confunde os gêneros. Há um propósito secreto para toda essa subversão: é transmitir subterraneamente, para outros agentes secretos da ascese e mística moderna (enquanto leitores implícitos), sua ligação íntima entre texto e experiência mística, que implica numa ascese em segundo grau de negar o comum, depois negar o reconhecidamente incomum, para então praticar uma vida extraordinária com status ordinário.

\section{Soltura abismal}

Água viva reitera também essa relação entre texto, ascese e mística.

Mas 9 e 7 e 8 são os meus números secretos. Sou uma iniciada sem seita. Ávida do mistério. Minha paixão pelo âmago dos números, nos quais adivinho o cerne de seu próprio destino rígido e fatal (LISPECTOR, 1973: 38).

Lembrando a relação entre seitas esotéricas e seu estudo da numerologia, desvendando o conteúdo simbólico dos números, a narradora diz que é uma "iniciada sem seita". Esse enunciado está aqui ligado aos números secretos, e ela os revela como secretos. Ter números secretos não diminui o desejo pelo mistério, parece, ao contrário, aumentar. A ânsia pelo mistério se 
efetiva na "paixão pelo âmago dos números", algo que estaria para além de sua função meramente instrumental na matemática cotidiana.

Contudo, não vejo aqui uma relação obscura da simbologia dos números com o texto. Assim como o "it", esse "mistério impessoal" (LISPECTOR, 1973: 35) por trás de todas as explicações, no âmago dos números a narradora encontra "seu próprio destino rígido e fatal", um aspecto do impessoal e do implacável que é próprio desse mistério de uma iniciada sem seita. Não é preciso de seita para se iniciar ao mistério, é necessário sim uma paixão sem limites pelo âmago do impessoal, rígido, fatal, fora do universo psicológico doméstico do narrador usual, que exige um discurso parte especulativo parte poético, ou seja, um pensamento poético para captar o âmago misterioso do que é impessoal, de uma alteridade radical à narradora, ou, se se quiser, especuladora apaixonada. Nas palavras do admirável filósofo-poeta Alberto Pucheu: "A palavra do pensamento poético ou da poesia pensante se caracteriza por uma sensibilidade materializante do admirável" (PUCHEU, 2007: 169). Aqui a sensibilidade extrema está direcionada, ao contrário, ao mais abstrato, os números, mas que são tão impenetravelmente secretos, são tão coisa-em-si quanto à substância material; e exigem o mesmo desmembramento recíproco entre poesia e pensamento. A falta de acontecimento narrativo, mais uma vez, é substituída por uma avidez pelo impensável, inenarrável, por um inefável aqui visto como impessoal e fatal.

Vou te fazer uma confissão: estou um pouco assustada. É que não sei aonde me levará esta minha liberdade. Não é arbitraria nem libertina. Mas estou solta (LISPECTOR, 1973: 39).

Tal liberdade assusta não só por não estar condicionada a um imperativo de entreter com uma intriga e seguir a máquina do encadeamento das ações. A liberação de uma estrutura narrativa reconhecível representa uma liberdade de espírito mais ampla. A epígrafe de Michel Seuphor se refere à libertação da pintura figurativa como meio de "evocar os reinos incomunicáveis do espírito" (LISPECTOR, 1973: 35). A soltura não é "arbitrária nem libertina", quer dizer, não deixa de ter um propósito, que é a própria avidez do mistério. A liberdade das possibilidades da escrita está submetida a essa paixão pelo desconhecido, mas por isso mesmo acolhe por demais o desconhecido no 
discurso e assusta pela sua soltura abismal. As regalias da escrita sem regras estão portanto ligadas à abertura da experiência para o não-vivenciado. Por isso não se dilui na mera arbitrariedade, o que tornaria o texto sem densidade existencial, nem é "libertina", não pretende liberar toda e qualquer perversão só pelo charme de estar transgredindo (lembremos da lúcida advertência de lumna Simon ao exibicionismo anal de Waldo Motta, que diminui suas qualidades artísticas: a radicalidade excrementícia do materialismo baixo de Bundo, temos de admitir, é o sucedâneo farsesco, com o mesmo pathos, de uma tentativa de emancipação SIMON, 2004: 230).

Assim como os libertinos entre si sempre negociam o que vão permitir e como, a narradora negocia com o mistério o que vai liberar em seu ato de escrita e como. Acrescentemos: assim como a dose de herança da ascese e mística tradicional negocia com os tesouros esquecidos da mística tradicional o que vai deslocar e inverter e como. A soltura assustadora vem não da arbitrariedade do gesto experimental, mas da capacidade de esse experimentalismo alcançar reinos desconhecidos da experiência. Não saber "onde levará essa minha liberdade" é já confessar que não se domina a liberdade que se põe a serviço da avidez do mistério. Liberdade literária sem mística não é mais do que gestos vazios do narcisismo criador. Todos os movimentos literários e, até hoje, todas as cartilhas de certos escritores e críticos pretendem impor, contra o gesto vão da escrita, diferentes asceses de escritura para dar alguma "lei do pai" ao caos narcisista da arbitrariedade. Mesmo não querendo impor nada a ninguém, cada escritor escolhe para si o que deve renunciar e o que vai explorar, constituindo assim uma ascese da escritura. Com isso sempre se arriscam a perder o potencial ignorado do que renunciaram, assim como podem ou não tirar bom proveito do que permitiram.

A estratégia de Clarice, nesse caso, é abrir mais as possibilidades não como forma "libertina" de aceitar qualquer coisa, todavia, pelo contrário, obedecer a uma ascese em que a própria soltura é a renúncia aos esquemas narrativos fáceis, em primeiro lugar, e também renúncia à liberação fácil. 0 critério de encaminhamento da escrita está no desejo ávido pelo mistério e na ascese que ele exige. Nesse caso, não há nem somente o despojamento ascético rumo à impessoalidade da barata e de Macabéa, como quer Benedito 
Nunes, nem a epifania na linguagem como graça profana, como quer Olga de Sá, contudo, além disso, há uma ascese da escrita rumo à prática de uma experiência do indizível, há um trabalho sacrificante e sacrificial da escrita, sutilmente dosado entre a liberação e o controle, direcionado para uma transformação existencial.

O resultado textual desse rigor em torno do impreciso se cristaliza numa narradora que sempre mostra seus sentimentos, reflexões e pitadas de prosa poética como atividade da busca pessoal. Por isso, o "eu" de Água viva não renuncia a um certo egocentrismo auto-divinatório que, contudo, não controla a si mesmo, não controla seu encontro com a onipotência silenciosa de Deus, e tem todo medo de se perder, "Ah tenho medo do Deus e do seu silêncio. Soume" (LISPECTOR, 1973: 35). Portanto, não se trata nem de um aniquilamento absoluto do eu diante do impessoal (como sugere Benedito Nunes), nem de uma recaída no romantismo, mas, ao contrário do que pensa Merquior, o fantasma romântico da divinização do eu mantém-se mesmo no cerne do mergulho no impessoal. Quando Benedito Nunes afirma que "nada separa a narradora da personagem" em A paixão segundo G.H., afirma ao mesmo tempo que "a personagem perde o seu eu e a narrativa, a sua identidade literária" (NUNES, 1989: 166). Apesar da grande acuidade e alcance filosófico do crítico, nesse momento a contemplação do inefável - que paira acima de qualquer narrativa e identidade - ofusca um exame de sua função na correlação com a posição do eu (da narradora, ou da personagem, ou de ambas) e com a estrutura narrativa, por mais que o crítico seja, justamente, um teórico da narrativa.

O mergulho no mundo, em Deus e no outro não deixa de motivar sempre o uso reiterado de uma narradora-pensadora em primeira pessoa. Se há restrição em sua liberdade de estruturação, está, para começar, no encaminhamento predominante que a narradora dá à escrita. Pensamos que o eu inevitável de Água viva testemunha, na sua própria atomização, o limite de um individualismo moderno que não pode fugir de si mesmo em direção à loucura sem se deparar com a sensatez relativa de seu olhar e a necessidade de compreensão do outro: "A loucura é vizinha da mais cruel sensatez. [...] Engulo a loucura que não é loucura - é outra coisa. Você me entende?" 
(LISPECTOR, 1973: 35). O esforço retórico no uso de paradoxos e construções negativas, que é recorrente na chamada mística especulativa herdada pela literatura moderna (WILLER, 2007: 79), exibe no seu excesso de linguagem, traduzido aqui por "loucura", o "canibalismo" da narradora - atuando como sujeito da experiência. Quem canibaliza a loucura é a experiência do sujeito e toda sua riqueza e extensão só ocorre no mundo da individualidade. Ainda que Regina Pontieri insista que "o ovo é interior e também exterior" (PONTIERI, 1999: 220) e repita o gesto desconstrutivo de desmontar as oposições contra expressões como "via introspectiva" (NUNES, 1989: 168), assim como o faz o próprio Benedito Nunes e Olga de Sá, que constatam a dissolução do eu na linguagem, o fato é que o eu insiste. Se não está lá mais como soberano cartesiano nem romântico -isso é evidente - a teoria tem dificuldade em pensar como um eu parcial, limitado, não deixa de ser inevitável na obra de Clarice, em especial - e isso é o mais surpreendente - nos textos mais experimentais. O fantasma romântico, denegado por Merquior, não é uma reencarnação, mas não pára de produzir seus efeitos. Penso que a negação exagerada do eu na teoria e na crítica provavelmente é uma reação antiromântica ainda romântica ao canto do cisne do romantismo.

Por mais que o eu queira se perder na embriaguez lúcida da linguagem - acesso privilegiado para o mistério inefável - ele só o faz nos confins de seu próprio desejo. Se ele quer o indizível, o cruel, o fatal, o rígido, o impessoal, o atemorizador, o louco, todo esse regime do inefável só é inefável para o sujeito que o deseja. De qualquer modo, só com a experiência do inefável - sua gnose inexplicável e a transmissão vaga e imprecisa do texto para o outro, o leitor - é que há algo mais para o sujeito do que a atomização social e cósmica. A loucura ameaçadora precisa ser canibalizada por um ser isolado, quer dizer, por uma, e uma só, boca. A luta contra o isolamento inevitável precisa do retorno ao entendimento, do uso parcial da razão, e mesmo do entendimento do outro, do entendimento sutil, íntimo, do que não é racional. Logo, há sempre fragmentação, soltura e depois retorno ao eu: intimidade e comunicação. Esse vai e vem quer ser também simultâneo.

Do ponto de vista do desejo do narratário, só um texto que "não é de ninguém", que pode ser usado para saciar e incitar a experiência e a gnose do 
inefável é digno de consideração: "Sim, o que te escrevo não é de ninguém. E essa liberdade de ninguém é muito perigosa. É como o infinito que tem cor de ar" (LISPECTOR, 1973: 100). A função (não estrutural, mas existencial) da ânsia de mistério inerente à escritura de Água viva é direcionada para a experiência do leitor. Em outras palavras, quer atemorizar o leitor com a possibilidade de uma experiência do excesso. Para sair da atomização social que o mundo administrado nos impõe, há de aterrorizar o enfraquecimento do sujeito coletivo com as forças perigosas da loucura canibalizada pela intimidade individual.

Textos de gozo desse tipo (retomando a expressão de Barthes) são importantes para desestabilizar a identidade narrativa (MCNAY, 2008: 102-103) do indivíduo que se configura nas micro-narrativas familiares e nas macronarrativas de nação, gênero e status. Como se observa, não haver trama em Água viva e em "O ovo e a galinha" significa não dar forma ficcional a nenhuma narrativa familiar e social. $\mathrm{O}$ eu do narrador mantém seu macrocosmo austeramente intocado por ficções tangíveis, por nomes, personagens delineados para interagirem. No conto há uma vaga noção de patrões e agentes, no livro há uma vaga noção de um tu que não adquire grande independência, apesar de raras vezes parecer ser motivo de queixa amorosa do eu. "Mas como fazer se não enterneces com meus defeitos, enquanto eu amei os seus" (LISPECTOR, 1973: 99). Como esse tu se confunde com o narratário, essa rápida sugestão de ser um ente ficcional mais concreto se dissipa no mesmo narratário. Se for o caso, a narradora pede para o leitor acolher os defeitos do texto assim como o texto acolhe os defeitos, as faltas, de todo e qualquer sujeito, ou seja, do leitor em potencial. Contudo talvez esse trecho também funcione como forma de o leitor não se identificar com o tu.

Se a identidade é um discurso narrativo, a leitura e escrita da narrativa sem história que levam a uma experiência inefável é um exercício ascético de desprendimento de nossa identidade narrativa, estendendo aqui a ascese pensada por Benedito Nunes ao efeito na leitura. Narrativas da indústria cultural, ao nos evadir de nossa narrativa e nosso protagonismo diante da realidade, fazem-nos esquecer do stress e da luta diária com aventuras imaginárias da ficção. Enquanto leitores ou espectadores, identificamo-nos com 
tipos ideais, ou nos envolvemos com algo que nos alivia da prisão de nossa própria história e identidade.

Mas em narrativas negativas e "perigosas" como a de Clarice, não substituímos a predominância da realidade com a do imaginário, mas com a do real: o inefável não é evasão, é uma ascese de imersão ávida no "âmago" da existência. A identidade narrativa comum é ameaçada. Curiosamente, há aqui, para quem se acostumou com tal ascese de leitura, também um alívio frente à realidade, não para dela fugir, mas para superá-la, momentaneamente, com o absurdo excesso do inefável. Mas para quem leva a sério a ascese da ascese proposta por Clarice, a experiência mística da literatura do excesso faz parte de uma outra identidade narrativa, uma narrativa ascética que quer tornar a identidade suficientemente flexível e manipulável para ir adentrando no mistério, fazer da vida um caminho sem volta e sem fim para as regiões perigosas, mas canibalizando-as com a lucidez do eu, quer dizer, com um horizonte narrativo individual. O desafio dessa identidade negativa é ser e nãoser, é, com a ascese, mover-se na narrativa da vida como a narradora se move em sua escrita: solta, leve, encarando o terror do desconhecido ao desembocar no "estado de graça", que constitui literalmente a última parte do livro. Quando se alcança uma espécie de serenidade mística, quando a soltura se torna sinônimo de leveza, a ascese e a lucidez se tornam sinônimo de descanso.

O estado de graça de que falo não é usado para nada. É como se viesse apenas para que se soubesse que realmente se existe e existe o mundo. Nesse estado, além da tranqüila felicidade que se irradia de pessoas e coisas, há uma lucidez que só chamo de leve porque na graça tudo é tão leve. É uma lucidez de quem não precisa mais adivinhar: sem esforço, sabe (LISPECTOR, 1973: 105).

No entanto, esses momentos de "epifania" profana, como quer Olga de Sá, alternam-se com sensações de mal-estar e tristeza vindas do próprio êxtase (LISPECTOR, 1973: 111). Inclusive é preciso sublinhar toda a "potência mobilizadora dos enredos" centrada no mal, "que se particulariza nas expressões sádicas", analisada por Yudith Rosenbaum (1999: 97). Mas o final de Água viva termina por reforçar o estado de serenidade: "Calma, alegre, plenitude sem fulminação. Simplesmente eu sou eu" (LISPECTOR, 1973: 115). 


\section{Vitória do fracasso}

Essa alternância perpétua entre prazer e dor ligados a intensos conflitos existenciais em busca de uma transformação da vivência cotidiana estabelecida parece encontrar ótima síntese num trecho chave de outro livro, $A$ paixão segundo G.H.:

A realidade é a matéria-prima, a linguagem é o modo como vou buscá-la - e como não acho. Mas é do buscar e não achar que nasce o que eu não conhecia, e que instantaneamente reconheço. A linguagem é o meu esforço humano. Por destino tenho que ir buscar e por destino volto com as mãos vazias. Mas - volto com o indizível. O indizível só me poderá ser dado através do fracasso de minha linguagem. Só quando falha a construção, é que obtenho o que ela não conseguiu (LISPECTOR, 1973: 178).

A linguagem é o modo de buscar a matéria-prima da realidade, não a estabelecida socialmente, mas àquela do objeto não-idêntico de Adorno, que se furta à própria simbolização lingüística, logo, para essa busca a linguagem é um instrumento destinado ao fracasso. O verbo ser no presente, ao dizer "a linguagem é", repetido, figura em si mesmo o quanto a busca por meio da linguagem faz da mesma o meio privilegiado do esforço existencial. Porém, da linguagem só sai o fracasso - a linguagem não é o inefável - mas o fracasso da linguagem é um sacrifício em prol de uma outra vitória, a da obtenção do indizível. Olga de Sá escreve acertadamente:

A linguagem fracassa, mas, sendo ainda fruto da linguagem, constitui a vitória da romancista. Porque assim a linguagem se revela falível e essencial, e a criação literária ganha sentido existencial (SÁ, 1979: 53).

Tal sacrifício é curiosamente feito a partir da "falha da construção", como se a estrutura lingüística não fosse mais do que um instrumento, uma máquina, um "robô", retomando a etimologia desta palavra, um escravo sacrificado. Ela é "meu esforço humano", mas pode ser abandonada quando fracassa, isto é, meu esforço humano é maquinal e só serve para ser sacrificado em nome do seu contrário, o indizível, o que não depende de esforço, o que está no âmbito de uma espontaneidade nunca codificada, em outras palavras, de um estado de graça. Mas quem, ou o quê, sacrifica a máquina de esforço humano da linguagem e obtém o indizível? Mais uma vez, há um "eu" sem subjetividade 
estável em jogo, porém que, por alguma alquimia hegeliana, absorve, "obtém" o indizível.

Rosenbaum observa acertadamente que há uma "experiência do sublime" enquanto "desmontagem dos códigos estabelecidos para que a criação se dê". Saindo da beleza da forma e operando uma "destruição do eu familiar" a idéia é "criar a partir do informe sem apoiar-se nos critérios da falicidade" (ROSENBAUM, 1999: 173). Contudo, observamos aqui a destruição da linguagem - condição de possibilidade do eu - em nome da obtenção de outro eu, certamente não familiar, um eu estranho, unheimlich, reaparição de um fantasma romântico, bem ao gosto de E.T.A. Hoffmann: um eu que obtém o indizível ao se perder, uma dialética hegeliana com fim e núcleo negativo, uma dialética negativa do eu, um eu negativo. Apesar da dificuldade de pensá-lo, Rosenbaum, baseando-se na aproximação do sublime com a diferença feminina de Joel Birman (1999: 172), emprega para isso a expressão de Birman "impessoalidade singular". Ela também cita uma passagem de Benedito Nunes de fato esclarecedora.

É o "paradoxo egológico" desse romance: a narração que acompanha o processo de desapossamento do eu, e que tende a anular-se juntamente com este, constitui o ato desse mesmo eu, que somente pela narração consegue reconquistar- se (NUNES, 1989: 76).

Embora ambos os críticos tenham sido nesses momentos mais felizes no apontamento do problema, falta perceber que não há renúncia do eu ao absoluto, mas há, sem dúvida, o sacrifício da linguagem e do eu familiar para alcançá-lo de algum modo estranho e indizível, certamente não fálico nem subjetivo, no entanto não menos ambicioso. A circular perda e reconquista de si mesmo (NUNES, 1989: 76) é, a meu ver, um processo incessante de busca, através da linguagem, da narrativa e da obra, de uma experiência que não se dá somente na linguagem, mas opera mediante a ascese da escrita. A obra da linguagem deve servir à experiência que a sacrificará. A grosso modo, o senhor, finalmente, é a experiência do inefável, inimiga da vivência cotidiana, que a aprisiona, - uma sorte de experiência mística moderna - e o escravo é a linguagem, máquina de guerra feita para fazer irromper o seu contrário: o indizível. Nesse caso, a função do inefável na narrativa não se restringe a uma 
estrutura textual nem a um poder sobrenatural, por isso devemos concordar com o jovem Luiz Costa Lima.

Não se trata de postular uma função misteriosa, mágica e inefável para a palavra. A palavra é um instrumento, que se modifica de acordo com a matéria que visa atingir (LIMA, 1966: 105).

Mas se trata, sim, de examinar a função do inefável na narrativa quando todo o esforço humano da linguagem luta em prol de uma experiência do inefável. E a função não pode ser outra senão escravizar e ser escravizado pela linguagem de modo que se atinja, por meio do "drama da linguagem", o que excede a linguagem e passa para o âmbito da experiência prática, da prática mais concreta da experiência extraordinária mais inapreensível. A função do inefável é levar a linguagem narrativa à auto-negação de modo a torná-la função do inefável, isto é, função da prática própria de uma busca mística secularizada. A função do inefável na narrativa é tornar a linguagem função do inefável.

Luiz Costa Lima foi o primeiro a perceber que a mística em Clarice se dá "ao revés", retomada em termos de epifania por Olga de Sá, complementando o comparativismo riquíssimo porém inexato de Benedito Nunes. A intuição de Luiz Costa Lima, a retomada mais sistemática de Olga de Sá e o alcance filosófico e existencial de Benedito Nunes (relacionando a obra com teologia negativa, ascese e mística especulativa) não tiveram continuidade substancial na crítica brasileira. Regina Pontieri retomou de forma interessante a teologia negativa em "O ovo e a galinha" (PONTIERI, 1999: 216-219), mas brevemente. A comparação de Igor Rossoni com o zen budismo, em 2002, ainda que interessante, regride o debate ao pouco se preocupar em apontar as diferenças e praticar um comparatismo de semelhanças, do qual Wagner-Egelhaaf, entre outros, já tinha nos desembaraçado. Há momentos sugestivos para pensar o que penso como prática transformadora da micro-experiência. Clarice produz um "laboratório auto-reflexivo", faz de si mesma um laboratório de investigações, evidenciando a própria individualidade, visando à experimentação pessoal (ROSSONI, 2002: 47).

O zen budismo, sendo uma prática mística tradicional, é uma tradição secular ligada à mesma busca, por isso Rossoni nos mostra correlações 
instrutivas, mas no geral confunde-se autor implícito com autor empírico, simplificando os problemas ao pensar que a busca é a da autora Clarice. De fato, a função do inefável na narrativa quer sair da linguagem, mas o ponto de chegada dela certamente não é uma regressão no biografismo da busca pessoal da autora e sim no efeito da busca, determinada pela linguagem e narrativa desmembrada, na leitura; ou seja, o que nos interessa é que o texto torna-se o ponto de encontro entre a busca do escritor e a busca do leitor, ponto esse que é o único rastro, tornado objeto, a ser analisável. O fracasso da crítica é perceber que a dimensão prática da experiência é indeterminável e o texto é sempre a única determinação (im)possível do inefável, que fracassa diante do inefável, mas vence diante do crítico.

O perigo dessas correlações entre mística e literatura está sempre em ignorar a peculiaridade da ascese mística da escrita própria da literatura moderna. Esse é o motivo pelo qual os críticos da mística se valem para desmerecê-la: quando a falta de discernimento teórico se apossa dos estudos da mística e confunde mal o objeto com o método.

Uma grande constatação de Luiz Costa Lima em 1966 ainda não foi, a meu ver, bem dimensionada nem por ele nem por ninguém, depois disso.

Não poderemos deixar de notar que $A$ Paixão Segundo G.H. problematiza não só a literatura, mas também a religião. Esta é a primeira vez, na literatura brasileira, que a religião é posta em discussão (LIMA, 1966: 125).

Seu erro foi em seguida comparar com Murilo Mendes e Jorge de Lima, que, por serem católicos, supostamente não seriam capazes de uma problematização radical, o que discordo, pois também não falta drama da linguagem e da religião nos dois poetas. Mas o nosso artigo pretende responder ao apelo do final do primeiro livro de Luiz Costa Lima, ainda que em outros termos: "a busca de incorporar o religioso à dimensão humana da práxis, do agir terreno" (LIMA, 1966: 126). Pois a questão é, justamente, que a transformação da práxis não se dá mais somente no nível político, mas da micro-experiência do instante, sendo ele político ou íntimo, nem é tal religiosidade mais ligada à "dimensão humana" nem à divindade tradicional, mas a algo inumano, inefável. 
Está na hora de, pela primeira vez, pôr em discussão a religião deslocada de forma insólita pela literatura. A mística medieval já foi, no seu tempo, um impulso herético do esclarecimento no seio da religião. A mística na literatura moderna - que seculariza a mística e, no entanto, faz com que a mística reconquiste a si mesma ao se perder fora da religião - é um impulso extático do próprio esclarecimento no seio da autonomia da literatura moderna, mas que serve, mais uma vez, ao esclarecimento, por vias tortas. A coincidentia oppositorum entre o impulso herético da mística medieval e o impulso místico da literatura moderna está no fato de que ambas não querem só doutrinas, tradicionais ou experimentais, ambas desejam o inefável, o fora da linguagem. Por isso a obra de Clarice inocula figurações do inefável na estrutura da narrativa de forma a inscrever furos na linguagem que as potencializa para que, enfim, todo o seu esforço dê lugar à experiência do inefável; em outras palavras: a experiência mística na prática da leitura.

\section{Referências Bibliográficas:}

BIRMAN, Joel. Cartografias do feminino. São Paulo: Editora 34, 1999.

BRASIL, Assis. Clarice Lispector. Ensaio. Rio de Janeiro: Organização Simões, 1969.

BROEK, Roelof van den \& HANEGRAAFF, Wouter J. (org.). Gnosis and hermeticism from Antiquity to modern times. New York: State University of New York Press, 1998.

CONNOR, Steven. Cultura pós-moderna: introdução às teorias do contemporâneo. São Paulo: Loyola, 1992.

FILHO, Adonias. "O conto e o monólogo". In: Modernos ficcionistas brasileiros. Rio de Janeiro: Tempo brasileiro, 1965, pp.81-83.

HELENA, Lucia. "A Problematização da Narrativa em Clarice Lispector". In Hispania. Volume 75. Número 5. Dec. 1992. [p. 1164-1173]

JAMESON, Fredric. Postmodernism, or, The cultural logic of late capitalism. Durham: Duke University Press, 1991.

KAWIN, Bruce R.. The Mind of the Novel: Reflexive Fiction and the Ineffable. Princeton: Princeton University Press, 1982.

LAFETÁ, João Luiz. 1930: A crítica e o modernismo. São Paulo: Duas Cidades/Ed. 34, 2000. 
LAYTON, Bentley (org.). As Escrituras Gnósticas. Edições Loyola: São Paulo, 2002.

LIMA, Luiz Costa. Por que literatura. Petrópolis: Vozes, 1966.

LISPECTOR, Clarice. Água viva. Rio de Janeiro: Artenova, 1973.

A paixão segundo G.H. Rio de Janeiro: Ed. do Autor, 1964.

1991.

Felicidade clandestina: contos. Rio de Janeiro: Francisco Alves,

LOSSO, Eduardo Guerreiro Brito. Teologia negativa e Theodor Adorno. A secularização da mística na arte moderna. 2007. Tese (doutorado em Teoria Literária)-Faculdade de Letras, Universidade Federal do Rio de Janeiro, Rio de Janeiro, 2007.

MCNAY, Lois. Against recognition. Cambridge: Polity, 2008.

MENKE, Christoph. The sovereignty of art. Aesthetic negativity in Adorno and Derrida. Cambridge: MIT Press, 1998.

MERQUIOR, José Guilherme. O fantasma romântico e outros ensaios. Rio de Janeiro: Vozes, 1980.

NUNES, Benedito. O drama da linguagem: uma leitura de Clarice Lispector. São Paulo: Ática, 1989.

PONTIERI, Regina. Clarice Lispector: uma poética do olhar. São Paulo: Ateliê editorial, 1999.

PUCHEU, Alberto. A fronteira desguarnecida: poesia reunida 1993-2007. Rio de Janeiro: Beco do Azougue, 2007.

RICOEUR, Paul. Time and Narrative. Chicago: University of Chicago Press, 1984.

ROBERTS, Tyler T.. This Art of Transfiguration Is Philosophy: Nietzsche's Asceticism. The Journal of Religion, v. 76, n. 3, jul. 1996, p. 402-427.

ROSENBAUM, Yudith. Metamorfoses do mal: uma leitura de Clarice Lispector. São Paulo: Edusp, 1999.

ROSSONI, Igor. Zen e a poética auto-reflexiva de Clarice Lispector: (uma literatura de vida e como vida). São Paulo: UNESP, 2002.

SÁ, Olga de. A escritura de Clarice Lispector. Petrópolis: Vozes, 1993.

SIMON, Iumna Maria. Revelação e desencanto: a poesia de Valdo Motta. Novos Estudos Cebrap. São Paulo, n. 70, nov. 2004, p. 209-233. 
WAGNER-EGELHAAF, Martina. Mystik der Moderne: die visionäre Ästhetik der deutschen Literatur im 20. Jahrhundert. Stuttgart: Metzler, 1989.

WILLER, Claudio Jorge. Um obscuro encanto: gnose, gnosticismo e a poesia moderna. Tese de doutorado, USP, São Paulo, 2007. 